Santa Clara University

Scholar Commons

History

College of Arts \& Sciences

Fall 2011

\title{
"Abortion Will Deprive You of Happiness!"Soviet Reproductive Politics in the Post-Stalin Era
}

Amy E. Randall

Santa Clara University, arandall@scu.edu

Follow this and additional works at: http://scholarcommons.scu.edu/history

Part of the Feminist, Gender, and Sexuality Studies Commons, and the History Commons

\section{Recommended Citation}

Randall, A. E. (2011). “Abortion Will Deprive You of Happiness!”: Soviet Reproductive Politics in the Post-Stalin Era. Journal of Women’s History, 23(3), 13-38. https://doi.org/10.1353/jowh.2011.0027

Copyright (C) 2011 Journal of Women's History. This article was first published in Journal of Women's History 23:3 (2011), 13-38. Reprinted with permission by Johns Hopkins University Press.

This Article is brought to you for free and open access by the College of Arts \& Sciences at Scholar Commons. It has been accepted for inclusion in History by an authorized administrator of Scholar Commons. For more information, please contact rscroggin@scu.edu. 


\title{
"Abortion Will Deprive You OF HAPPINESS!"
}

Soviet Reproductive Politics in the Post-Stalin Era

\author{
Amy E. Randall
}

This article examines Soviet reproductive politics after the Communist regime legalized abortion in 1955 . The regime's new abortion policy did not result in an end to the condemnation of abortion in official discourse. The government instead launched an extensive campaign against abortion. Why did authorities bother legalizing the procedure if they still disapproved of it so strongly? Using archival sources, public health materials, and medical as well as popular journals to investigate the antiabortion campaign, this article argues that the Soviet government sought to regulate gender and sexuality through medical intervention and health "education" rather than prohibition and force in the postStalin era. It also explores how the antiabortion public heal th campaign produced "knowledge" not only about the procedure and its effects, but also about gender and sexuality, subjecting both women and men to new pressures and regulatory norms.

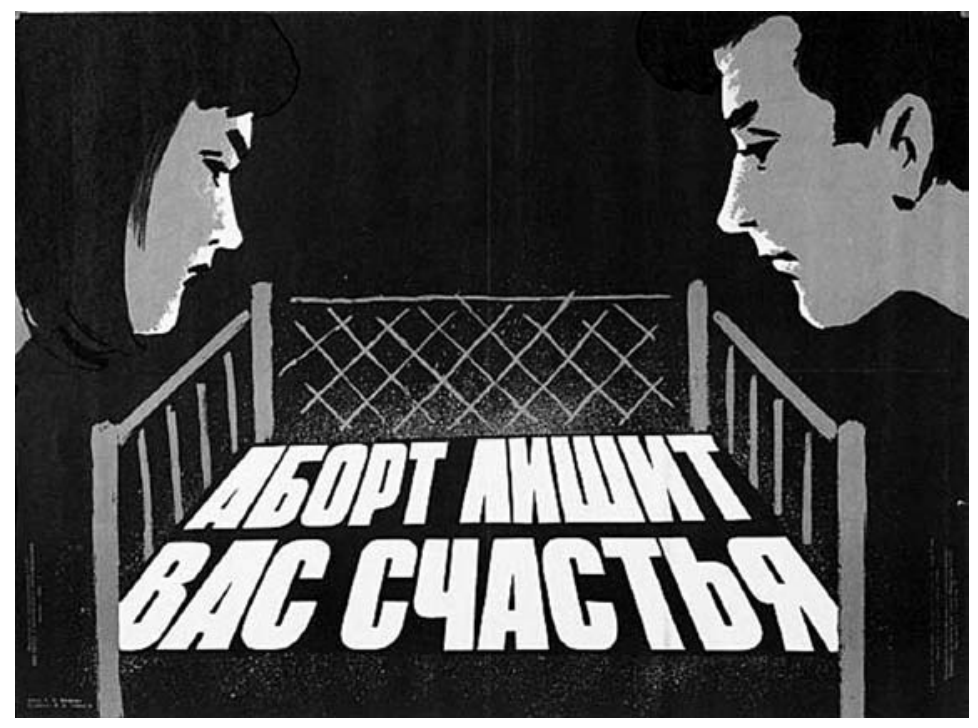

Figure 1. V. Stepanov, "Abort lishit vas schast'ia" (Abortion will deprive you of happiness), 1966. Courtesy of the Russian State Library.

(c) 2011 Journal of Women's History, Vol. 23 No. 3, 13-38. 

$\mathrm{A}_{\text {with the words "Abortion will deprive you of happiness." }}^{\text {f1 (Figure 1) }}$ This image surprisingly was not produced when abortion was outlawed in the Soviet Union but rather in 1966, many years after abortion was, for the second time, legalized. A product of the antiabortion campaign that accompanied the legalization of abortion in 1955, the poster illustrates two of the campaign's main narratives: that abortion could destroy a woman's reproductive capacity and that it could destroy family happiness. Viewed in historical context, the image reflects and reinforces broader efforts to exert "soft" control over the Soviet population in the post-Stalin era through reconfiguring gender roles and sexual norms.

Communist authorities first legalized abortion in 1920, only to change course during the Stalin era and recriminalize it in 1936 (except for very limited medical conditions). Whether abortion was criminalized or legalized, abortion policy in both the pre and postwar eras was justified in the same way: concern for women's wellbeing. ${ }^{2}$ The 1955 policy shift was the culmination of growing concern in the late 1940s and early 1950s among Soviet officials and medical personnel about the high number of illegal abortions and their associated costs. The government initially resisted decriminalizing abortion, instead expanding antiabortion education, the medical policing of reproduction, and the range of medical conditions under which abortion was authorized. But after Stalin died in 1953, new government reports reconfirmed the hazards of underground abortion, detailing approximately 4,000 annual deaths as well as many other problems that impaired women's procreative abilities. Anxiety about the illegal procedure's negative effects on women's health contributed to the decision to relegalize abortion. ${ }^{3}$

The change in abortion policy was also a product of broader pronatalist angst about the nation's "long-term rates of conception and birth" and the demographic consequences of dangerous illegal abortions. ${ }^{4}$ This is not surprising; Soviet abortion policy, in its various incarnations, was always accompanied by official pronatalism. Communist leaders consistently touted motherhood as a social duty and developed state policies and services to encourage women to reproduce. ${ }^{5}$ Soviet pronatalism was not unique; many governments throughout Europe adopted measures to increase birthrates, particularly in the interwar era and after World War Two. ${ }^{6}$ What was unusual in the Soviet case was the conjunction of state pronatalism with the legalization of abortion and promotion of contraception. In other European countries, official interest in boosting reproduction-intensified by wartime casualties-meant that abortion remained illegal and contraception was outlawed or limited. The Soviet Union faced a particularly devastating demographic crisis after World War Two: approximately twenty-six million soldiers and civilians had perished. These staggering wartime losses gave 
impetus to pronatalist measures and propaganda. ${ }^{7}$ Interestingly, the very year that the government decriminalized abortion, Khrushchev trumpeted the great need to increase Soviet fertility, proclaiming: "The more people we have, the stronger our country will be." ${ }^{8}$ But even if Khrushchev's interest in boosting the birthrate might seem at odds with the regime's decision to allow abortion and contraception, pronatalism explicitly informed this policy shift. ${ }^{9}$ Soviet officials and medical experts hoped that legalization would strengthen the nation's reproductive health, since they believed the illegal termination of pregnancy adversely affected women's long term ability to procreate to a greater extent than medicalized abortion. A similar logic contributed to the endorsement of contraceptives; authorities thought their use would result in fewer illegal and legal abortions, both of which were deemed detrimental to women's fertility.

The government's pronatalist agenda was reflected directly in the text of the 1955 decree. It paternalistically claimed that "measures carried out by the Soviet state to encourage motherhood and protect infancy, as well as the uninterrupted growth of the consciousness and culturedness (kul'turnost') of women," allowed for the change in abortion policy. ${ }^{10}$ Governmental aid for reproduction and women's greater maturity, the decree implied, meant that most women would choose motherhood over abortion. In marked contrast to the 1920 decree, the 1955 decree recognized a woman's right to control her reproduction. But it also made clear that authorities did not condone abortion and that preventing the procedure remained a key goal. Even without legal prohibition, the decree declared, abortions could be limited by increasing state resources for mothers and expanding education.

The 1955 decree decriminalized abortion as long as it was conducted "in hospitals or other medical institutions." ${ }^{11}$ As the historian Deborah Field notes, the 1955 abortion law thus "called for both greater individual freedom and increased intervention in women's reproductive lives." 12 Indeed, whether the issue was abortion or birth control, the antiabortion campaign suggested that women not seek to control their fertility without consulting medical authorities. Women were warned that some health conditions made abortion advisable, even if potentially hazardous, for pregnancy would be even riskier. Other conditions meant that even "if a woman did not want to keep a pregnancy," abortion was simply too dangerous. Noting that preventative devices suitable for some women were unsuitable, even unsafe, for others, health pamphlets similarly cautioned women interested in contraception to seek medical advice. ${ }^{13}$ By framing pregnancy, abortion, and contraception as potential health hazards that required expert guidance, the antiabortion campaign reinforced the regime's ongoing efforts to medicalize reproduction. 
The change in abortion policy was part of a broader reconfiguration of party-state control after Stalin's death in 1953. Under Nikita Khrushchev's leadership, the Soviet regime promoted a series of reforms, "de-Stalinization," and a cultural "thaw." Yet even as Khrushchev's regime repudiated the violent coercion and punitive excesses of Stalinism, it still sought to discipline the everyday lives and practices of citizens. Thus the regime exhorted the populace to pursue the tenets of "Communist morality," a longstanding objective that was reinvigorated and formalized as a twelve-point moral code at the 1961 Twenty-Second Communist Party Congress. This code "imposed both public and private obligations, demanding orderly personal conduct in addition to patriotism, diligence, and activism." During this period, citizens were subjected to greater efforts to regulate personal behavior via the expansion of mechanisms for mutual surveillance-such as people's patrols-and greater official attention to and punishment of unseemly practices, including activities deemed sexually immoral or deviant. ${ }^{14}$ Soviet officials, professionals, and the media expressed increased interest in the domestic sphere and women's societal roles, suggesting a new spirit of intrusiveness regarding these matters. ${ }^{15}$ The regime's simultaneous legalization of abortion, and antiabortion campaign, are properly understood within this larger context.

Using archival sources, public health materials, and medical as well as popular journals, this article examines Soviet reproductive politics from the mid-1950s to approximately 1970, focusing on the antiabortion campaign as a window on Communist techniques for governing in the post-Stalin era. ${ }^{16}$ It argues that the campaign served to reinforce official pronatalism in the wake of abortion's legalization, and that it contributed to shifts in official Soviet discourse about the family, sexual norms, and gender roles, including constructions of masculinity. As the article shows, a tension between relatively emancipatory and traditionalist impulses marked not only abortion policy but the broader Soviet approach to gender, sexuality, and society during this time. Reproductive politics epitomized this tension.

\section{Reproductive Health, Motherhood, and Happiness}

As abortion was reframed as a medical matter rather than as a criminal affair, the imperative to regulate reproductive behavior via persuasion acquired new saliency. Pursuing the 1955 decree's directive to increase educational efforts to combat abortion, public health officials and activists as well as medical personnel were largely responsible for the discursive explosion that followed. ${ }^{17}$ Reaffirming the regime's pronatalism, they characterized abortion as a "serious evil," which could damage a woman's health, deprive her "of the happiness of motherhood" and negatively affect "family relations." 18 
As educators conducted the antiabortion campaign, they drew upon strategies that had begun to be more actively promoted in the early 1950 s as concerns about illegal abortion grew: spreading awareness about the procedure via lectures, popular-scientific literature, posters, and the press. ${ }^{19}$ Compared to this earlier agitation, the campaign of the late 1950s and 1960s was more expansive, targeting a larger audience. A "huge army of obstetricians and gynecologists" engaged in the "struggle against abortion" at maternity homes, ob-gyn departments at hospitals, nursing-midwife "points," and women's consultation clinics, where women received gynecological and obstetric care. Medical personnel talked about abortion with the general female public - not just with patients for whom pregnancy was risky or who had just terminated their pregnancies (the primary emphasis of earlier educational efforts). With the motto that "It is better to prevent pregnancy than to terminate one," personnel sought to increase awareness about birth control. ${ }^{20}$ In 1959 alone, women's clinics and similar facilities in the Samarkand Oblast organized 555 lectures and 7,570 talks about abortion and contraception. ${ }^{21}$ Antiabortion posters and pamphlets, photo exhibits, wall newspapers, and "boards of questions and answers" provided patients with additional information. One year, for example, women's clinics in Bashkir ASSR organized ninety-one photo exhibits on "What is necessary to know about the dangers of abortion." Although efforts to encourage birth control were stymied by widespread contraceptive shortages, educators nonetheless publicized a variety of devices, including condoms, cervical caps, rubber diaphragms, spermicidal creams, and vaginal sponges or wadded tampons doused in vinegar, boric acid, or dairy acid, and some women's facilities even sold them. ${ }^{22}$

The antiabortion campaign was an all-union affair-conducted in Russian as well as Tatar, Uzbek, and other non-Russian languages throughout the Soviet Union. Regional and cultural differences informed the campaign. Thus, for example, medical personnel and public health officials in Uzbekistan emphasized the particular dangers of abortion for female minors, because underage marriage remained a problem in Central Asia, notwithstanding its illegality. ${ }^{23}$ Despite some differences, however, the campaign's basic contours appear to have been the same: to promulgate the dangers of abortion, even medicalized abortion, among the broader Soviet populace, and to spread pronatalist propaganda. As a result, educational efforts targeted not only women's medical facilities but also industrial enterprises as well as non-workplace settings, such as workers' dormitories and clubs, secondary and post-secondary schools, and various public venues. ${ }^{24}$ In 1956, for example, medical workers organized over 20,000 antiabortion lectures and talks throughout Tashkent. ${ }^{25}$ Public health activists from "sanitary enlightenment houses" arranged screenings of antiabortion films, including 
"This doesn't happen without consequences," first released in 1950, and at least eight other films produced between 1956 and 1967. ${ }^{26}$ Lectures and literature on a "girl's hygiene," the "hygiene of youth," and the "hygiene of marriage," including those sponsored by "universities of health for women" and "for youth," also publicized the perils of terminating a pregnancy. ${ }^{27}$ So too did the radio and printed press-particularly Zdorov'e, a health journal with a circulation of millions in the mid-1960s, and women's journals such as Sovetskaia zhenshchina and Rabotnitsa. ${ }^{28}$

Although medicalized abortion was certainly not without its dangers in the 1950s and 1960s, the government's education strategy was not nonpartisan: the point was to discourage abortion by highlighting its risks and costs, even in misleading ways, and to teach the Soviet populace to "be afraid of abortion." 29 Thus antiabortion rhetoric characterized women as victims who had "to survive the severity of abortion" and its "frequent" adverse effects. ${ }^{30}$ The campaign made use of the most well-known victim of illegal abortion, the character Natalia from Mikhail Sholokhov's interwar novel, Quiet Flows the Don, which remained very popular in the post-Stalin era and was made into an award-winning three-part epic film in the late 1950s. Relying on the novel and film's cultural currency, public health literature referred to Natalia's death to highlight the genuine peril of underground abortion, which women continued to resort to for personal as well as other reasons, despite the change in Soviet abortion policy. ${ }^{31}$ Instructional materials for the antiabortion campaign recommended reading audiences an excerpt from the novel, because it had a "significant emotional impact on women listeners." 32 Some educators clearly heeded this advice. In lecturing to women workers, for example, one doctor narrated the consequences of Natalia's botched abortion: "How terribly Natalia had changed in one night! Only the day before she had been like a young apple tree in blossom-beautiful, healthy, strong, but now her cheeks looked whiter than the chalk of the Donside hills, her nose had narrowed, her lips had lost their former clear freshness ..." To accentuate the tragedy of the situation, the doctor reminded listeners that Natalia was already the mother of two children, and described her ultimate demise. ${ }^{33}$

Although health professionals and educators acknowledged that medicalized abortion was safer than underground abortion, they still described it as dangerous or "extremely dangerous." 34 Underscoring the "great trauma" that abortion caused to the positive and "complex restructuring of the organism" that commenced with pregnancy, they characterized it as an invasive operation. ${ }^{35}$ Antiabortion campaigners also claimed that medicalized abortion rarely "proceeded without consequences." 36 Seeking to challenge popular misconceptions that abortion was a "simple" opera- 
tion, they underscored how the procedure required doctors to carry out "fairly complicated manipulations" without being able to see what they were doing. ${ }^{37}$ Moreover, they argued, abortion heightened women's risk of infection. Even medical personnel who carefully followed sanitary rules did not always succeed in eliminating microbes that could endanger a woman's health, a particular problem given that the uterus and cervix's "wounded surfaces" made them more susceptible to contagion. ${ }^{38}$ Abortion-related infection often led to subsequent problems that were not always immediately obvious-for example, inflammation of the internal genitalia and infertility-leading women to believe, wrongly, that termination produced no long term consequences. Women aborting first pregnancies reportedly were most likely to suffer from such difficulties. ${ }^{39}$ "The termination of a first pregnancy," medical expert Nikonchik opined, "often cripples a woman's life and deprives her forever of the ability to become a mother." ${ }^{40}$ A health pamphlet declared: "How many blossoming young healthy women have become infertile as a result of this first abortion, becoming permanent patients of women's clinics, dreaming about pregnancy and motherhood!"41

By underscoring abortions' health risks, educators hoped to deter women from pursuing them. But if the threat of medical complications and reproductive problems did not serve as a deterrent, antiabortion discourse offered additional reasons to avoid the procedure: the risk to sexual feeling and the threat of premature aging. "After an abortion," publications cautioned, "sexual desire in a woman often decreases and sometimes completely disappears." Public health materials also claimed that women who terminated pregnancies aged more quickly than those who "fulfilled their natural destiny: birthing children." Signs of this premature aging included the early graying of hair, the emergence of wrinkles, the loss of "turgor and elasticity" in the skin, and perimenopausal symptoms. ${ }^{42}$

In accentuating abortions' hazards, some of the campaign's "scare tactics" were worse than others. Particularly egregious was one pamphlet, About the Danger of Abortion, which explained: "... regardless of its outcome ... abortion is a drama, and not infrequently a serious tragedy, particularly for young women in the prime of life and health," who become "victims of abortion, ruining their health in some cases for many years and at other times forever, becoming invalids or even paying with their life." ${ }^{43}$ Such alarmist rhetoric differed dramatically from the far more benign depiction of medicalized abortion presented in five international studies from the mid-1950s to the mid-1960s. These studies indicated that the procedure caused few serious complications such as inflammatory disease or infertility. Soviet medical reports on the procedure's adverse effects were meanwhile inconsistent, suggesting at times that it caused infertility in 2.6 percent of 
women and at other times that it caused infertility in 35 percent of women. Nonetheless, the antiabortion campaign painted a uniformly grim picture, emphasizing the possibility of dire consequences. ${ }^{44}$ Not unlike public health education about venereal disease, which exaggerated or lied about its dangers "to terrorize young people into toeing the official line," the antiabortion campaign evoked people's fears in an effort to control them. ${ }^{45}$

With a demonstrable natalist agenda, the campaign also reminded the Soviet people that motherhood was a "government necessity." ${ }^{46}$ This was not a new idea; the Communist government had long conceived of motherhood as a civic responsibility. ${ }^{47}$ Writings and lectures about abortion underscored the obligation of women as Soviet citizens to become mothers and raise "healthy, cheerful children who [were] not afraid of difficulties" and who were "worthy of this wonderful epoch in which we live." ${ }^{48}$ Articles pointed out how the birth of a child was good for society, and how new generations labored "on behalf of the further strengthening and flourishing of [the] motherland." ${ }^{49}$ By characterizing reproduction as a national priority and societal obligation, antiabortion materials implicitly characterized abortion as contrary to national interests and women's civic duties. ${ }^{50}$

The campaign depended upon a naturalized definition of motherhood. It claimed that all Soviet women aimed to become mothers, that motherhood was an "instinct of every woman," and that there was "no greater happiness for women than the happiness of motherhood." ${ }^{51}$ Texts additionally asserted, "Motherly feeling is an inexhaustible source of energy, which makes a woman's life complete and happy." ${ }^{52}$ According to this pronatalist rhetoric, choosing motherhood was natural whereas choosing abortion was unnatural. Highlighting this message, one health poster featured a mother gazing lovingly at her infant with the text: "And I wanted to have an abortion ..." Fortunately for this mother and baby, the poster suggested, the right decision had been made, and happiness and health had been preserved. ${ }^{53}$ Educational materials often included "letters" from or stories about happy mothers who had almost terminated but then continued their pregnancies, similarly emphasizing the rightness of choosing motherhood over abortion. ${ }^{54}$

Antiabortion discourse proposed that women's yearning for motherhood, and the joy they derived from being mothers, were the main reasons why abortion, and the subsequent infertility supposedly caused by it, could be so devastating. Even if women had fulfilling marital relationships as well as "interesting and wonderful work," their barrenness and desire for a child would give rise to a sense of dissatisfaction and a "less than complete life." ${ }^{55}$ "Stop!," one poster warned, "Now abortion seems necessary, but remember, it might forever deprive you of the happiness of motherhood!" Featuring a woman's shapely leg in pink hosiery and a fashionable high-heeled shoe 
stepping on the stem of a blue flower, this poster marked the leg as that of a presumably young woman taking a careless and destructive step. Young women, the image conveyed, should not take the decision of abortion lightly and destroy what is beautiful and natural: motherhood, symbolized by the flower. Drawing attention to the emptiness that a childless woman would supposedly feel, another poster depicted a sad looking matreshka (wooden nesting doll) opened up without anything inside and cautioned: "Abortion threatens infertility." ${ }^{\prime 56}$ By pursuing abortion, a health pamphlet similarly proposed, a woman could "not be confident about the possibility of becoming a mother in the future." 57

Why did I do that?, a public health film released in 1956, emphasized how ending pregnancy could lead to such a catastrophic outcome. This widely-shown film featured two women: vibrant Lena, who is planning an abortion until confronted by Katya, who shares her terrible story about the procedure's pernicious effects. As Katya's tale unfolds, viewers learn of Katya's romance with Victor, their marriage, and Katya's pregnancy. Victor responds to the news of pregnancy with fear, anxiety, and then resignation "that it wouldn't be so bad to become a father," dampening Katya's initial enthusiasm. Seeking advice, the couple turns to Victor's mother, who reacts with bleak words: "There will be diapers, sleepless nights ..." In the end, Katya obtains an abortion. At first there are no noticeable repercussions. But then the film reveals that the procedure has greatly impaired Katya's reproductive ability. The movie ends with a second meeting between Lena and Katya. Here it becomes apparent that Lena, despite her earlier intentions, ultimately decided against abortion. Lena is presented as a happy mother, who, unlike the unfortunate Katya, has avoided a "horrible mistake." Katya, meanwhile, still suffers from her abortion's consequences, and it is not clear if she will ever be able to bear a child. ${ }^{58}$ This movie impressed upon viewers the necessity of choosing motherhood over abortion for protecting future health and happiness.

Abortion-related infertility reportedly undermined not only personal happiness but also "family" happiness-that is, the happiness of women and men, wives and husbands. Antiabortion images emphasized this effect by including men as victims of such infertility and suggesting that as potential fathers, they too suffered. One poster, for example, represented a woman and man as two birds looking down at an empty nest with tears in their eyes, accompanied by the message: "Abortion can lead to irreparable misfortune." Conveying the same basic message, but highlighting the joy of parenting instead of lost opportunity, another poster featured a mother's and father's faces smiling at a happy baby and declared: “Don't be deprived of happiness!" 59 
In addition to such illustrations, which underscored how abortion could destroy family happiness, health literature repeatedly asserted that abortion-related sterility and the subsequent lack of children in a family "can lead to family conflict and not infrequently serves as a reason for divorce." 60 What Every Woman Should Know recounted the story of a woman whose marriage and happiness were in jeopardy because of an abortion from her midtwenties, which had resulted in inflammatory disease, a lengthy hospital stay, and numerous other problems, including pelvic pain and loss of sexual feeling. After years of trying to get pregnant, this woman was desperate to become a mother at the age of thirty-five. As she explained to her doctor, her husband was threatening divorce because of her inability to conceive. ${ }^{61}$ Emphasizing the likelihood of marital discord because of abortion-related sterility, antiabortion propaganda frequently referred to supposedly true narratives of husbands abandoning their newly infertile wives. ${ }^{62}$

Tales of abandonment and the destruction of marriage were meant to impress upon women the double tragedy of abortion: it could leave them without children and without husbands. The idea that abortion-related infertility would lead to a life of loneliness, a life without a family or marriage, was vividly conveyed. One poster showcased the silhouette of a woman perched on a huge rock, with her back hunched forward, elbows on knees, and head bent forward, a position suggesting despair. The woman's slim figure, attractive legs, high heels, and hair style suggested her youthfulness (and unmarried status). The poster offered two signs of the woman's sterility: the background of barren trees and the huge rock. According to popular folklore, sitting on a hard or cold surface could destroy a woman's reproductive organs. This image of despair and infertility was accompanied by the words: "Abortion has dangerous consequences. Don't condemn yourself to solitude!"63 (See figure 2.) Echoing this sentiment, a health pamphlet argued that "if young women could imagine fully the difficulty of solitude in old age," they would avoid abortion, which leads to such "sad consequences." 64 Yet another poster asserted the connection between abortions' hazards and a life without a family more emphatically. "Infertility and bitter loneliness," the text declared, "are common consequences of abortion." On the poster's left side was a young boy's smiling face. The right side featured a lone woman with brow furrowed and mouth downturned, clutching a shawl tightly around her shoulders. The woman's expression and shawl signaled that she was very unhappy and probably middle-aged, suggesting she had been "alone" for some time. Unlike the boy's face, which was surrounded by light, the image of the woman was cloaked in darkness, underscoring her misery and solitude. A potted plant instead of a family kept this tragic woman company, fulfilling the prophecy quoted above. ${ }^{65}$ (See figure 3. ) 


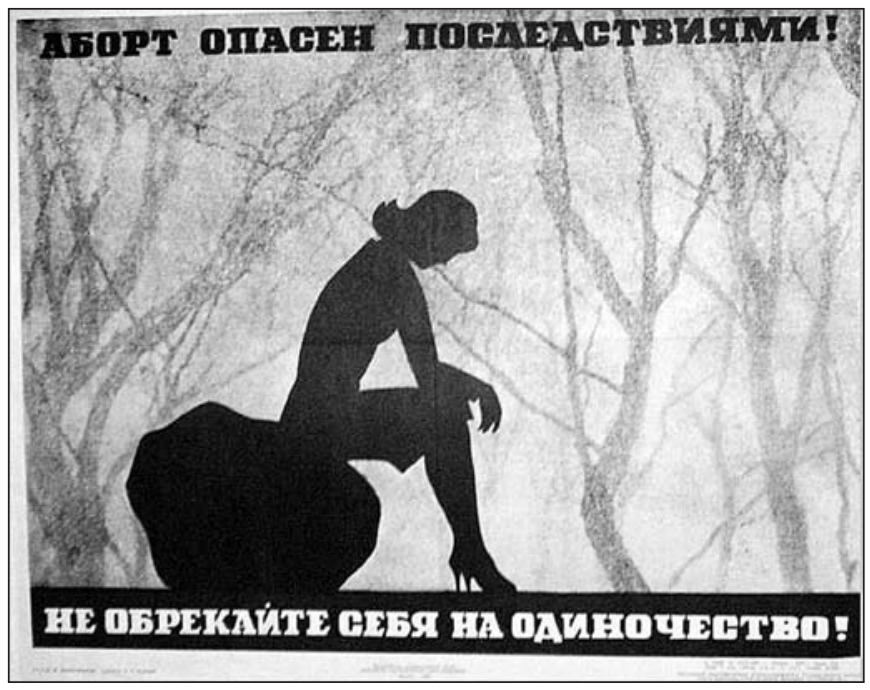

Figure 2. A. Rudkovich, "Abort opasen posledstviiami! Ne obrekaite sebia na odinochestvo!" (Abortion has dangerous consequences. Don't condemn yourself to solitude!), 1965. Courtesy of the Russian State Library.

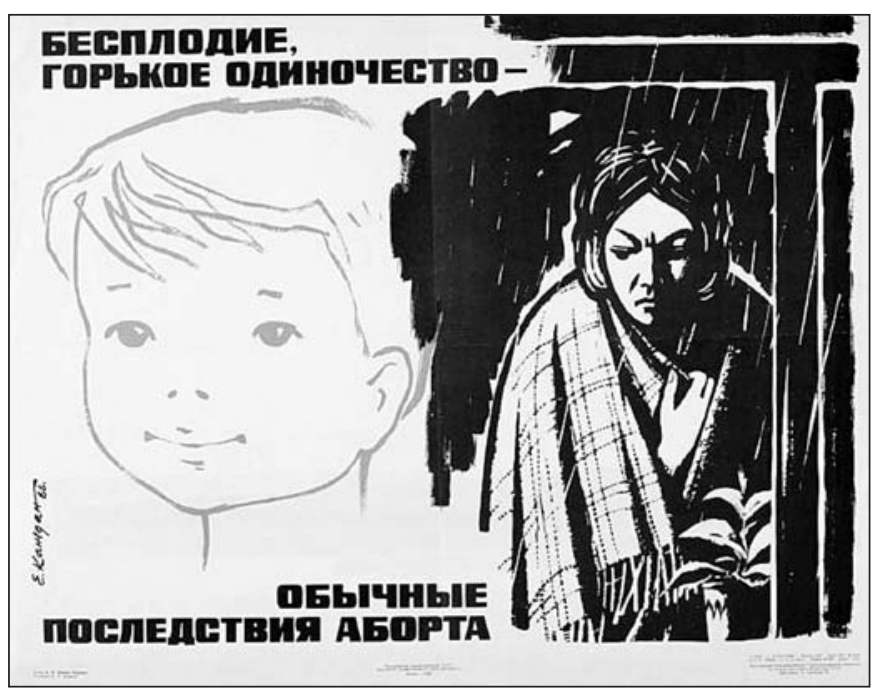

Figure 3. A. Kazhdan, "Besplodie, gor'koe odinochestvo obychnye posledstviia aborta" (Infertility and bitter loneliness are common consequences of abortion), 1966. Courtesy of the Russian State Library. 
By focusing on marital problems and spinsterhood as possible consequences of abortion, the campaign reaffirmed a normative nuclear model of the Soviet family: one with a mother and father. This familial image marked a shift in emphasis from the iconography of the Soviet family in the immediate postwar era, in which "single-mother" families figured prominently. During this time, women's journals depicted single motherhood as not only acceptable but even desirable in certain situations. ${ }^{66}$ These journals and the press more generally displayed ideal Soviet women as "single women with children and full and happy lives." Articles celebrated single mothers, detailing how they managed with government assistance to raise children and pursue full-time work without a spouse ${ }^{67}$ Genre painting portrayed women as successful heads of households with thriving children but no husbands. ${ }^{68}$ Although the two-parent nuclear family remained central in official Soviet discourse, single-mother families were legitimized and images of the "lone mother" and "fatherless children" abounded. ${ }^{69}$

To some extent, this representation of the "single-mother" family was rooted in reality: after the wartime death of millions of men, many widowed mothers raised families alone. But this representation was also reflective of the Communist regime's interest in increasing the country's birthrate, an interest reinvigorated by wartime losses. Women's necessary single parenthood and the regime's natalist agenda led to a new Family Law in 1944 that legitimized "single motherhood as [a] site of reproduction" by sanctioning, indeed rewarding, "illegitimate" births. This law forbade unmarried women from claiming child support from the fathers of their "out-of-wedlock" children or from naming the fathers on their children's birth certificates. Instead of paternal support, the government promised financial aid to single mothers, reinforcing women's relationship with the state (and not with their male partners). By relieving men of familial responsibility, the law encouraged men, "both single and married, to impregnate millions of women, many of whom became the 'new single mothers' of the postwar era." In the late 1940s and early 1950s, "single-mother" families became an increasing reality. Whereas 280,000 unmarried mothers received government aid in 1945 , by 19573.2 million did. ${ }^{70}$

\section{Husbands and Fathers in the Service of the State}

The antiabortion campaign's emphasis on the two-parent family entailed a reconceptualization of men's familial roles. The campaign reconstructed men as "responsible" Soviet citizens who had domestic duties, serving to promote a new image of husbands and fathers in the post-Stalin era. This family vision assigned men a central role, standing in stark contrast to representations of the Soviet family in the immediate postwar period, 
in which men were frequently eliminated or marginalized. In postwar imagery, husband-fathers were typically absent, as if nonessential, in articles featuring married working mothers. The Soviet press did not usually depict men as supportive spouses or active caregivers. ${ }^{71}$ Moreover, family men were often portrayed negatively-as drunkards or as "wounded souls" with mutilated bodies, veteran-husbands whose loving wives took care of them. ${ }^{72}$ Meanwhile, as poems, articles, and other materials celebrated the robust and wise "father" Stalin and his accomplishments, Stalin served as the symbolic father for a Soviet populace ravaged by the Second World War. ${ }^{73}$

This postwar marginalization of men in the domestic sphere followed decades of earlier marginalization. As scholars have pointed out, during the 1920s the domestic power of husbands and fathers was curtailed because of the adoption of new family laws, divorce procedures, and the medicalization of motherhood. ${ }^{74}$ By politicizing motherhood and characterizing it as a "noble and rewarded service to the state," Communist authorities meanwhile diminished fathers' position in the family and served to exclude them from the "state-mother-child triad." ${ }^{\prime 75}$ Husbands' command over wives was further reduced during the drive for rapid industrialization as women entered wage labor en masse and secured greater economic independence. The wife-activists movement of the 1930s, which granted wives a major role in the campaign for kul'turnost' (culturedness), including the disciplining of men, also lessened men's domestic authority. ${ }^{76}$ Even though the government endorsed the nuclear family in the interwar era, and indeed sought to strengthen it in the mid 1930s when it enacted new legislation which made divorce more difficult, outlawed abortion, and reconfirmed fathers' duty to provide child support, authorities did not promote men's supremacy in the domestic sphere as husbands or fathers. As the social psychologist Sergei Kukhterin notes, the "[s]tate did not give institutional support to male dominance in the family, rather it supported the cause of women as a force for order on the home front." 77 Even if patriarchal gender relations in the domestic sphere still prevailed and men continued to wield power, authorities moreover encouraged men to realize themselves at work or in the battlefield, not in the family. Not surprisingly, given the persistence of Soviet pronatalism and wartime exigencies, despite men's marginalization in the domestic sphere Communist leaders did not exclude them from the responsibility to procreate. A 1941 decree that taxed the "childless," including men, and extended the system of "categorizing citizens by reproductive contribution to the state," a system that had previously focused on women's contributions, reinforced this male obligation. ${ }^{78}$ Yet although the government expected men to procreate, the new Family Law of 1944 clarified that men were not required to marry the women they had sexual relationships with or support the offspring of their liaisons. As these examples suggest, 
from the 1920s to the Stalin era, the Soviet regime largely emphasized men's procreative role, not their fatherly or husbandly role, and masculinity was defined primarily by what men did in the public sphere.

The antiabortion campaign of the late 1950s and 1960s helped to domesticate Soviet masculinity by reconfiguring men's roles in the reproductive sphere and the family. The campaign promoted abortion as a husbandly concern and fatherly matter. One way it did so was by emphasizing how abortion threatened family happiness, including the husband's: if a wife became infertile after having an abortion, the husband would eventually leave the wife so he could become a father, or he would remain in the marriage, unhappy because of his inability to realize fatherhood. Embedded in this narrative was the assumption that fatherhood, like motherhood, was natural. Sometimes this assumption was made explicit: "The instinct of motherhood and fatherhood is a part of the very nature of human beings. The lack of children gives rise to difficult feelings in the wife as well as the husband, involving an unsatisfactory life, and often leads to the severance of family relations." ${ }^{\prime 79}$ In contrast to the immediate postwar era, when the Soviet regime encouraged men to impregnate women but not necessarily assume any familial responsibilities, this rhetoric suggested that marriage and fatherhood were critical to a man's identity.

Men were included not only in antiabortion discourse but also in the campaign's broader educational work. Thus many doctors and other health educators targeted men in public lectures and talks. ${ }^{80}$ Medical personnel, for example, organized antiabortion lectures for men in Sevastopol in 1961. In the first half of 1966, women's consultation clinics arranged similar talks for male workers at several large industrial enterprises in Tashkent. ${ }^{81}$ This agitation was considered necessary because it was "well known that many men don't take very seriously the abortions carried out by their wives." ${ }^{82}$ In addition, "Men [were] not completely competent about the hygiene of sexual life." As one health educator explained, "They usually receive medical information about abortion from their wives, whom they don't always believe, because they think that their wives exaggerate everything with the goal of frightening them." ${ }^{83}$ Such ignorance was problematic because of men's perceived influence on women's reproductive decisions. A husband often knew early on about his wife's pregnancy and "by his reaction to it, passively or actively impelled a woman to terminate the pregnancy." ${ }^{84} \mathrm{Men}^{\prime} \mathrm{s}$ ignorance, plus "egotistical reasons," led them to conclude that abortion was "the best way out of a situation." 85 Ideally, if men were taught about the potential risks involved, they would not pressure women to have abortions and they might even become more proactive partners. When medical personnel in Rostov on the Don refused to perform abortions for women pregnant for the first time until after they had met with the women's hus- 
bands, their meetings reportedly yielded some success; about 10 percent of the wives subsequently refrained from the procedure. ${ }^{86}$ According to an instructional pamphlet for medical personnel, it was imperative to conduct antiabortion propaganda among men that emphasized "their responsibility for a wife's health and family happiness." ${ }^{\prime 87}$

Outreach to the male population included many visual and textual materials which were explicitly designed to speak to men and women. One brochure noted that while women would probably constitute its main audience, it was possible that the reader would be a man "concerned about his future fatherhood." 88 After first addressing female readers, another pamphlet turned to male readers "who sometimes, unfortunately, do not want to know abortion and its dangerous consequences." The pamphlet asserted: "We intend this brochure to be not only for women but also men." Why? Because "it was not a secret that quite often a woman decides to have an abortion not on her own, but under the influence or even pressure of a husband." Before a husband pushed his wife "to have an abortion or gave in to her regarding this," the text advised, he should "seriously think about the harmfulness and perils of abortion." 89

The antiabortion campaign's focus on men represented an attempt to advance new social expectations about their domestic duties. Health materials not only included men as readers (at least some of the time), they also assigned them greater responsibility for reproductive decision-making than earlier antiabortion materials-which often ignored men's influence on women's decision to terminate, and, in some cases, even attributed influence to "the reaction" and "behavior" of nearby women friends and relatives.$^{90}$ In addition to blaming men for abortions, these later antiabortion texts frequently admonished men to help reduce them. One pamphlet explained: "The theme of abortion is incorrectly considered a woman's." Yet it argued that husbands needed to be concerned with the issue. After all, "[i]f a husband insisted on the birth of a child, it was a rare wife who decided to go against his wishes and have an abortion." Even though many men tried to avoid "the question of preserving or terminating a pregnancy, and [did] not express their opinion, hoping to leave the decision" to their wives, "[t]his behavior of a husband is completely incorrect." It was both the wife's and the husband's "responsibility" to decide whether "to birth a child or not, preserve the health of a woman or risk it, strengthen the family or take a step towards its possible destruction." ${ }^{\prime 1}$ In calling upon men to act as a "positive" force in reproductive decision-making, antiabortion rhetoric advanced the idea that men needed to defend their wives, future children, and the institution of marriage.

This 1962 poster underscores the ways in which the campaign reenvisioned men's roles. The poster makes clear that abortion is a man's 
concern with the text, "For you comrade men," in the largest letters. It then explains: "Don't be surprised, comrade men, that we have decided to talk with you about such an intimate topic as abortion. Of course, first and foremost this problem concerns women, but you should also know why abortion is harmful. Wouldn't you try to find the most convincing words to keep your beloved woman, your true friend, from this hasty step? Would you really remain indifferent to that which might deprive her of the happiness of motherhood?"92 In another section of the poster entitled, "Abortion doesn't happen without consequences (a conversation of two women)," men are depicted as integral to reproductive decision-making. The first woman discusses how she and her husband long for another child. The problem is that earlier they opted for an abortion, which damaged her fallopian tubes and made it unlikely she would ever become a mother again. The second woman explains that she really wants a daughter but is considering an abortion because she doesn't have a big apartment and her husband wants to wait to have children. The first woman responds by arguing that living in a better apartment without the "voice" and "laughter" of a child will be "depressing." She urges the second woman and her husband to think seriously about this before it is too late, hinting at the possibility of abortion-related infertility. This "conversation" casts men as both wrongheaded proponents and victims of abortion. The voice of authority in the poster, "a doctor," similarly reproaches husbands for sometimes exercising a negative influence on women and pressuring them to get an abortion: "a frequent cause of infertility." The doctor then underscores the absurdity and error of men's actions by invoking the idea that the yearning for fatherhood is instinctual. "There will come a time when an ardent desire arises in the husband for his wife to bear a child. You see, in every man there is the longing for fatherhood." By naturalizing fatherhood, this poster promoted it as an essential component of Soviet masculinity. The "doctor" also chastised men who sought to avoid the question of abortion, hoping to leave "the right" to decide to their wives. Such behavior was never correct. After all, "who, if not the husband, the father of the future child, should protect the health and life of a wife, the happiness of the family?" The image of the woman and man in the bottom right of the poster serves as an additional rebuke to apathetic men. In between a sad-looking woman and an indifferent-looking man are the words: "Citizeness G. S. Pukhova goes to terminate her pregnancy (for her own reasons)." The message? If only the man has cared enough to intervene ... A poem about abortion by the famous Soviet poet, Margarita Aliger (on the left side), laments the loss of a "little boy" due to a man's negative reaction to a woman's pregnancy. Had the man supported the pregnancy, the poem suggests, the woman would have taken a different path. As this poster demonstrates, by appealing to 
husbands to shield their pregnant wives and potential children from harm and assume more authority in the household, the antiabortion campaign promoted patriarchal gender norms: men were encouraged to assert their manhood by acting as responsible and protective husbands and fathers. (See figure 4.)

The reconceptualization of masculine identity advanced by the antiabortion campaign was part of a larger discursive shift in constructions of Soviet masculinity. If in earlier Soviet times, as well as the Stalin Era, a man's identity was tied predominantly to his actions and sacrifices in labor and the public sphere, and to his ability to become an exemplary "son," by the late 1950s and 1960s official discourse began to ascribe greater significance to his activities in the domestic sphere. Public health efforts that extended beyond the topic of abortion reinforced men's roles as husbands and fathers. New initiatives were launched to instruct men to defend the health of women. ${ }^{93}$ At the Cheliabinsk metallurgical factory, for example, educators arranged weekly evening classes for husbands of pregnant women on the topic of "Guard the health of your wife" and "How to greet the newborn," with a reported audience of 1,271 men. ${ }^{94}$ When pedagogues and others urged parents to instill the newly codified "Communist morality" in children, they assigned fathers a more active familial role. Although fatherhood continued to be defined in terms of "negative behaviors" such as drunkenness that "fathers should avoid," it was also defined more positively, in terms of concrete responsibilities that a father should undertake. Pedagogical literature and "minors' commissions" (volunteer groups formed to work with difficult children) instructed fathers to provide children with "intellectual stimulation and cultural enlightenment" - by taking them to theaters, movies, and museums. ${ }^{95}$ If before the Second World War and in the 1940s it was unusual for men to be censured or expelled by the Party merely for their husbandly and fatherly conduct, during the Khrushchev era, the Party placed greater emphasis on men's family behavior and disciplined members "who abandoned their children, beat their wives, created an unhealthy family environment through constant squabbling, or broke up another citizen's marriage." ${ }^{\prime 6}$ After the death of Stalin-the patriarch of the Great Soviet Family-real "flesh and blood fathers" reappeared on the screen, "along with a refreshingly new awareness of their anxieties and internal contradictions." ${ }^{\prime 97}$ During this time new attention was also paid to the father-figure in sports propaganda. ${ }^{98}$

Although in the post-Stalin era the Communist regime never relinquished its patriarchal authority over citizens, and official discourse still encouraged men to realize their manhood in the public sphere, changes in conceptualizations of Soviet masculinity were nonetheless afoot. The antiabortion campaign facilitated this transformation of manhood because 


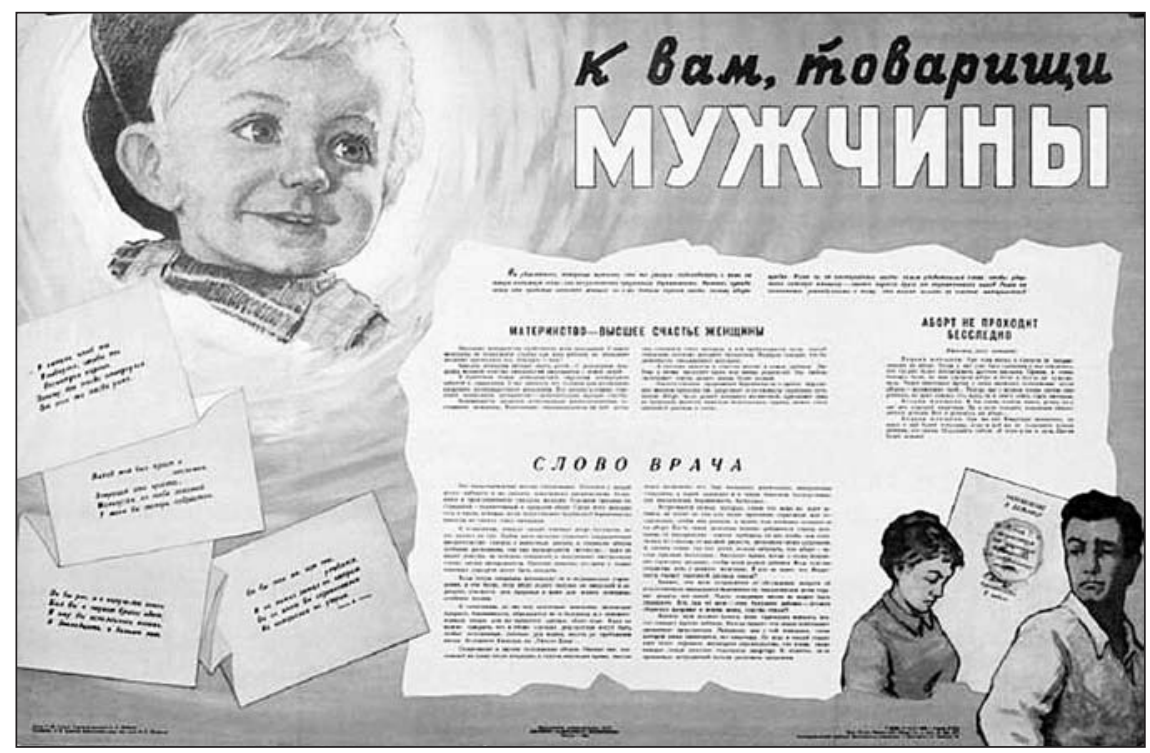

Figure 4. L. Aristov, “K vam, tovarishchi muzhchiny” (For you, comrade men), 1962. Courtesy of the Russian State Library.

it promoted a different vision of the Soviet family — one that moved away from men's marginalization as husbands and fathers and instead urged men to perform their masculinity by serving as more explicit heads and masters of their families. Official discourse significantly shied away from encouraging husband-fathers to dominate their wives or assume complete control over the domestic sphere. Men were instead expected to assist women in their capacities as worker-mothers, protect their health, and promote the interests of the family, which would naturally coincide with the Communist regime's interests.

\section{Conclusion}

The 1955 legalization of abortion made it easier for Soviet women to regulate their fertility. The state's simultaneous endorsement of contraception sanctioned women's greater control over their bodies. No doubt many women perceived these changes as empowering. But as the antiabortion campaign unfolded, health officials and medical professionals subjected women to intense pressure and "education" to reject abortion, a coercive form of persuasion that undermined women's reproductive autonomy. Poor access to contraception and the abysmal conditions under which legal 
abortions were provided, including assembly-line fashion and without anesthetic, likewise undercut the empowerment of women. ${ }^{99}$ Because the government failed to ensure an adequate supply of contraceptives, abortions indeed remained a de facto method of birth control. By enjoining men to intervene in reproductive matters, the antiabortion campaign also weakened women's authority over their bodies and the family, at least rhetorically, and increased the social costs of remaining unmarried. In this broader context, women's ability to choose or reject pregnancy was legally enhanced but nonetheless still limited in the post-Stalin era.

The antiabortion campaign contributed to the reconstruction of Soviet masculinity by assigning men a larger role in safeguarding reproduction and their families. This was part of a broader process: with the death of Stalin, the "universal father," official discourse began to ascribe greater authority to men in the domestic sphere. Discursively, however, men's power was constrained because the Soviet regime did not champion men's dominance over women and because the government retained its role as supreme patriarchal authority. The flip side of authority, moreover, was responsibility. Men were expected to alter their behavior and become more conscientious husbands and fathers. Assigning men greater domestic accountability was probably welcomed by many people, especially women, who criticized the 1944 Family Law for encouraging immoral male sexual behavior and increasing the number of "lone mothers" and "fatherless children" who suffered "social, moral, and economic problems" because of their status. ${ }^{100}$ Shifts in expectations about men's family roles during this period interestingly presaged a broader focus in the 1970s on Soviet masculinity and men's alleged degeneration. ${ }^{101}$

Soviet technologies of power underwent an important modification in the post-Stalin era. As authorities resorted less frequently to overt violence, prohibition, and punishment as methods for governing, the exercise of control via "normalizing" techniques—an already existing strategy—became even more important. Soviet reproductive politics exemplifies this shift. Although no longer banned, abortion was medicalized, which shifted the locus of the state's control of sexuality from legal punitive institutions to medical, educational, and social institutions and increased the professional regulation of women's bodies. The antiabortion public health campaign moreover produced "knowledge" not only about the procedure and its effects but also about gender and sexuality, which subjected both women and men to new pressures and regulatory norms. As the campaign sounded the alarm about infertile spinsters and their sad lives of solitude, and directed men to assume a greater role in reproductive decision-making and the family, health educators and medical personnel promoted the regime's pronatalist agenda, reaffirmed the importance of the two-parent family, 
and advanced a more familiarized and "responsible" heterosexuality that supposedly served the interests of individuals as well as the state. The campaign ultimately helped to spread a more diffuse system of coercive techniques for disciplining citizenly behavior.

\section{NOTES}

I would like to thank Naomi Andrews, Mathew Reed, and the anonymous reviewers of the Journal of Women's History for their constructive criticism and thoughtful comments. Thanks also to Khurshida Abdurasulova, for research assistance, and to Dan Healey for his feedback on an abridged version presented at the European Social Science History Conference. Santa Clara University provided financial support for this project-for which I am most grateful.

${ }^{1}$ Russian State Library in Moscow, Graphics Division (hereafter RGB), Inv \#7752.

${ }^{2}$ Wendy Goldman, Women, The State and Revolution: Soviet Family Policy and Social Life, 1917-1936 (Cambridge: Cambridge University Press, 1993), 256, 291; Susan Solomon, "The Demographic Argument in Soviet Debates over the Legalization of Abortion in the 1920s," Cahiers du monde russe et sovietique 33:1 (1992): 59-82; Frances Bernstein, The Dictatorship of Sex: Lifestyle Advice for the Soviet Masses (De Kalb: Northern Illinois University Press, 2007), 169-70; Rudolf Schlesinger, ed., Changing Attitudes in Soviet Russia: The Family in the U.S.S.R. (London: Routledge and Kegan Paul, 1949), 271; Sbornik zakazov SSSR i ukazov Prezidiuma Verkhovnogo Soveta SSSR, 1938-1975, tom 3 (Moscow: Izd. izvestiia sovetov deputatov trudiashchikhsia SSSR, 1975), 306; Mark Field, "The Re-legalization of Abortion in Soviet Russia," New England Journal of Medicine Vol. 255 (1956): 421-7.

${ }^{3}$ After Stalin's death, the Soviet Supreme Court also absolved women of criminal responsibility for seeking illegal abortions. Christopher Burton, "Minzdrav, Soviet Doctors, and the Policing of Reproduction in the Late Stalinist Years," Russian History/Histoire Russe 27, no.2 (2000): 216-7; Mie Nakachi, Replacing the Dead: The Politics of Reproduction in the Postwar Soviet Union, 1944-1955 (Ph.D. dissertation, University of Chicago, 2008), chap. 5 and 6.

${ }^{4}$ Nakachi, Replacing the Dead, 477.

${ }^{5}$ Goldman, Women, The State and Revolution, 291; Mie Nakachi, “N. S. Khrushchev and the 1944 Soviet Family Law: Politics, Reproduction, and Language," East European Politics and Societies 20, no.1 (2006): 40-68.

${ }^{6}$ David Hoffmann, "Mothers in the Motherland: Stalinist Pronatalism in its Pan-European Context," Journal of Social History 34:1 (2000): 35-54; Dagmar Herzog, "Sexuality, Memory, Morality," History and Memory 17 (2005): 238-66; Clare Duchen, Women's Rights and Women's Lives in France 1944-1968 (London: Routledge, 1994), chap. 4. 
"Nakachi, "Khrushchev"; Greta Bucher, Women, the Bureaucracy and Daily Life in Postwar Moscow, 1945-1953 (Boulder, CO: East European Monographs, 2006), chap. 7.

${ }^{8} \mathrm{O}$. Nikonchik, "Problema kontratseptsii i organizatsiia bor'bu s abortami," Akusherstvo i ginekologiia (hereafter AG) 6 (1959): 4.

${ }^{9}$ David Heer also argues that legalization was not antinatalist in "Abortion, Contraception, and Population Policy in the Soviet Union," Soviet Studies 17, no.1 (1965): 76-83.

${ }^{10}$ Sbornik, 306.

${ }^{11}$ Ibid.

${ }^{12}$ Deborah Field, Private Life and Communist Morality in Khrushchev's Russia (New York: Peter Lang, 2007), 57-60; Melanie Ilič, "Women in the Khrushchev Era," and Susan Reid, "Women in the Home," Women in the Khrushchev Era, eds. Melanie Ilič, Susan Reid, Lynne Attwood (Basingstoke, UK: Palgrave, 2004), 9 and 160 , respectively.

\section{${ }^{13}$ Aida Dobrovol'skaia, Vred aborta (Moscow: Meditsina, 1964), 14, 22.}

${ }^{14}$ Field, Private Life, especially page 9; Oleg Kharkhordin, The Collective and the Individual in Russia (Berkeley: University of California Press, 1999); Brian LaPierre, "Making Hooliganism on a Mass Scale: The Campaign against Petty Hooliganism in the Soviet Union, 1956-1964," Cahiers du monde russe 1-2 (2006): 1-28; Edward Cohn, Disciplining the Party: The Expulsion and Censure of Communists in the PostWar Soviet Union, 1945-1961 (Ph.D. dissertation, University of Chicago, 2007); Dan Healey, Homosexual Desire in Revolutionary Russia: The Regulation of Sexual and Gender Dissent (Chicago: University of Chicago Press, 2001), 238-44. As Healey notes, the Stalinist anti-sodomy law was renewed in 1958 and "the result of de-Stalinization for men and women who expressed same-sex desire [was] increased surveillance and incarceration," 238.

${ }^{15}$ See Ilič, Reid, and Attwood, eds., Women in the Khrushchev Era.

${ }^{16}$ Scholars have pointed to the development of an antiabortion campaign in the 1970s and 1980s. This article shows that this campaign began much earlier. Whereas antiabortion rhetoric during later years questioned the morality of abortion, that of the late 1950s and 1960s did not. For the later campaign see Christopher Williams, "Abortion and Women's Health in Russia and the Soviet Successor States," in Women in Russia and Ukraine, ed. Rosalind Marsh (Cambridge: Cambridge University Press, 1996), 131-55; Michelle Rivkin-Fish, "From 'Demographic Crisis' to 'Dying Nation,'" in Gender and National Identity in Twentieth-Century Russian Culture, eds. Helena Goscilo and Andrea Lanoux (De Kalb: Northern Illinois University Press, 2006), 155-73. For abortion in Imperial Russia see Laura Engelstein, "Abortion and the Civic Order: The Legal and Medical Debates," in Russia's Women: Accommodation, Resistance, Transformation, eds. Barbara Evans Clements, Barbara Alpern Engel, Christine Worobec (Berkeley: University of California Press, 1991), 185-207. For abortion in post-Soviet Russia see Tomasz Wites, "Abortions in Russia Before and After the Fall of the SU," Warszawa 11 (2004): 217-28. For abortion during the 1920s 
and 1930s, see notes 2-6; Paula Michaels, "Motherhood, Patriotism, and Ethnicity: Soviet Kazakhstan and the 1936 Abortion Ban," Feminist Studies 27 no.2 (2001): 315-6; Natalia Lebina, "Abortnaia politika kak zerkalo sovetskoi sotsial'noi zaboty," in Sovetskaia sotsial'naia politika 1920-1930-x godov (Moscow: Variant, 2007), 228-41.

${ }^{17}$ The mandate to conduct antiabortion education was reaffirmed in subsequent decrees by the Ministry of Health, such as one issued to republican branch ministries in 1962. See Tsentral'nyi Gosudarstvennyi Arkhiv Nauchno-Tekhnicheskoi i Meditsinskoi Dokumentatsii Respubliki Uzbekistan (Central State Archive of Scientific, Technical, and Medical Documents of the Republic of Uzbekistan, hereafter TsGA NTMD UR), f. 1 (UzSSR Ministry of Health), o. 4, d. 669, 11. 137-137ob.

${ }^{18}$ O. Nikonchik, “Dal'neiushie puti snizheniia chisla abortov," AG 2 (1963): 92.

${ }^{19}$ Gosudarstvennyi Arkhiv Rossiiskoi Federatsii (State Archive of the Russian Federation, hereafter GARF), f. 8009 (USSR Ministry of Health), o. 22, d. 227; Burton, 201, 212-3.

${ }^{20}$ Nikonchik, "Dal'neiushie," 92; idem, "Gosudarstvennaia okhrana zdorov'ia zhenshchin i detei," Sovetskoe zdravookhranenie (hereafter SZ) 6 (1960): 11; E. Sadvokasova, Sotsial'no-gigienicheskie aspekty regulirovaniia razmerov sem'i (Moscow: Meditsina, 1969), 125-8; Fel'dsher i akusherka (hereafter FA) 3 (1968): 40.

${ }^{21}$ TsGA NTMD UR, f. 1, o. 3, d. 1311, 1. 37.

${ }^{22}$ GARF, f. 482 (RSFSR Ministry of Health), o. 54, d. 2624, 1. 53; o. 50, d. 8521, 1. 109 ; f. 8009 , o. 50, d. 2295, 11. 54, 114; O. Nikonchik, Abort i protivozachatochnye sredstva (Leningrad: Medgiz, 1961), 29-39.

${ }^{23}$ TsGA NTMD UR, f. 1, o. 4, d. 124, 11. 9-10, 18, 21, 23, 77; o. 5, d. 810, 1. 3. In future work I plan to discuss how regional and cultural differences intersected with the new abortion policy.

${ }^{24}$ GARF, f. 482, o. 54, d. 2624, 1. 53; f. 8009, o. 50, d. 3022, 11. 154, 191.

${ }^{25}$ TsGA NTMD UR, f. 1, o. 5, d. 721, 1. 71.

${ }^{26}$ GARF, f. 482, o. 50, d 1862, 1. 28; TsGANTMD UR, f. 1, o. 4, d. 124, 11. 149-50; Sadvokasova, Sotsial'no-gigienicheskie, 128; Meditsinskaia sestra 11 (1965): 53.

${ }^{27}$ GARF, f. 482, o. 54, d. 2624, 1. 53; A. Gabelov, Gigiena braka (Moscow: Meditsina, 1965), 52-3; V. Khrenova, Gigiena devochki, devushki, zhenshchiny (Moscow: Institut sanitarnogo prosveshcheniia, 1963), 34; Nikonchik, "Dal'neiushie," 93-94.

${ }^{28}$ TsGA NTMD UR, f. 1, o. 3, d. 1311, 1. 20; Malinovskii, “Da, abort—eto zlo," and "Oshibka molodykh suprugov," Sovetskaia zhenshchina 9 (1956): 45-6, and 2 (1960): 31; Maizel', "Ne lishaite sebia materinstva!" and Levitin, "Ne gubite sebia," Rabotnitsa 11 (1957): 31, and 4 (1961): 30.

${ }^{29}$ Zdorov'e 12 (1963): 17.

${ }^{30}$ Nikolai Granat, Posledstviia aborta (Moscow: Meditsina, 1966), 32. 
${ }^{31}$ Ibid., 22; Nikonchik, Abort, 23-24. In future work, I plan to explore why women continued to seek illegal abortions after 1955.

${ }^{32}$ Nikolai Granat, Abort (Moscow: Institut sanitarnogo prosveshcheniia, 1957), 33, 47-50; Meditsinskaia sestra 11 (1965): 53, and 11 (1966): 51.

${ }^{33}$ TsGA NTMD UR, f. 192, o. 1, d. 56, 11. 8-9.

${ }^{34}$ Khrenova, Gigiena devochki, 34.

${ }^{35}$ Nikonchik, Abort, 24; Ia. Dul'tsin, O vrede aborta (Leningrad: Medgiz, 1960), 42; Murzalieva and Mel'nikova, "Chem opasen i vreden abort," Chto dolzhna znat' kazhdaia zhenshchina (Alma Ata: Izd. Kazakhstan, 1966), 100; Zdorov'e 12 (1963): 17.

${ }^{36}$ I. Kosoi, Abort ne prokhodit bessledno (Moscow: Institut sanitarnogo prosveshcheniia, 1956); Nikonkich, Abort, 8. $30-31$.

${ }^{37} Z$ dorov'e (1956): 10; Dobrovol'skaia, Vred aborta, 12; Dul'tsin, O vrede aborta,

${ }^{38} Z$ dorov'e 12 (1963): 17; Dobrovol'skaia, 17.

${ }^{39}$ Granat, Posledstviia, 24-25, 27; Nikonchik, Abort, 19, 26-7; Zdorov'e 3 (1956): 10; 3 (1967): 14; A. Verbenko et al., Aborty i protivozachatochnye sredstva (Moscow: Meditsina, 1968), 16; Kosoi, Abort ne prokhodit bessledno, 22.

${ }^{40}$ Nikonchik, "Problema," 6.

${ }^{41}$ Gabelov, Gigiena braka, 52.

${ }^{42}$ Nikonchik, Abort, 9, 28; Dult'sin, O vrede aborta, 44; Granat, Posledstviia, 22-23.

${ }^{43} \mathrm{Dul}$ 'tsin, O vrede aborta, 3.

${ }^{44}$ Because four of the five international studies came out of Sweden, Norway, Czechoslovakia, the GDR, there is a good chance they would have been available to the Soviet medical establishment. Lawrence Lader, Abortion (Indianapolis: BobsMerrill, 1966), 17-18. Of course medical conditions in different countries affected the safety of medicalized abortion, which limits international comparisons. For inconsistent Soviet data on abortions' effects, see Zdorov'e 3 (1956): 11; SZ 6 (1961): 20; Voprosy okhrany materinstva i detstvia 2 (1966): 81; 13 (1968): 64-66.

${ }^{45}$ Michael Stern and August Stern, Sex in the USSR (New York: Times Books, 1980), 133-4.

${ }^{46} Z$ dorov'e 3 (1956): 11.

${ }^{47}$ Olga Issoupova, "From Duty to Pleasure: Motherhood in Soviet and PostSoviet Russia," in Gender, State, and Society in Soviet and Post-Soviet Russia, ed. Sarah Ashwin (London; New York: Routledge, 2000), 30-54.

${ }^{48}$ Kosoi, Abort ne prokhodit bessledno, 18.

${ }^{49}$ Malinovskii, “Da,” 46; Zdorov'e 3 (1956): 11. 
${ }^{50}$ I. Bogorov, Gigiena zhenshchiny (Leningrad: Obshchestvo po rasprostraneniiu politicheskikh i nauchnykh znanii, 1960), 57.

${ }^{51}$ Kosoi, Abort ne prokhodit bessledno, 15, 20; Zdorov'e 3 (1956): 10; Dobrovol'skaia, 5 .

${ }^{52 N i k o n c h i k, ~ A b o r t, ~ 6 . ~ A l s o ~ s e e ~ Z d o r o v ' e ~} 3$ (1956): 10.

${ }^{53}$ Poster 158 in Materinstvo $i$ detstvo $v$ russkom plakate (Moscow: Kontaktkul'tura, 2006).

${ }^{54}$ Kosoi, Abort ne prokhodit bessledno, 23-26.

${ }^{55}$ Ibid., 15; Zdorov'e 3 (1956): 10.

${ }^{56}$ RGB, Inv \# 10408 and 1130.

${ }^{57}$ Nikonchik, Abort, 9.

${ }^{58}$ Zdorov'e 2 (1957): 27-28.

${ }^{59}$ RGB, Inv \# 19114 and 4962.

${ }^{60}$ Dul'tsin, O vrede aborta, 38-9, 43; Gabelov, Gigiena braka, 52; Zdorov'e 3 (1956): 10.

${ }^{61}$ Murzalieva and Mel'nikova, “Chem opasen i vreden abort," 99-100.

${ }^{62}$ Malinovskii, "Da," 45-6; Dul'tsin, O vrede aborta, 41; Dobrovol'skaia, Vred aborta, 21.

${ }^{63}$ RGB, Inv \# 7704.

${ }^{64}$ Kosoi, Abort ne prokhodit bessledno, 18.

${ }^{65}$ RGB, Inv \# 7428.

${ }^{66}$ Lynne Atwood, Creating the New Soviet Woman (Basingstoke, UK: MacMillan, 1999), 161-163.

${ }^{67}$ Greta Bucher, "Struggling to Survive: Soviet Women in the Postwar Years," Journal of Women's History 12:1 (2000): 146. Bucher refers to eight different newspapers and journals. Also see Rabotnisa 4 (1949): 6; 4 (1950): 29; 2 (1955): 1.

${ }^{68}$ Reid, “Women in the Home," 149-51.

${ }^{69}$ Helene Carlbäck, "Lone Mothers and Fatherless Children" in Soviet State and Society under Nikita Khrushchev (London; New York: Routledge, 2009), 86-103.

${ }^{70}$ Nakachi, "Khrushchev," 46-47, 60; Carlbäck, "Lone Mothers," 91.

${ }^{71}$ Bucher, "Struggling," 148. 
${ }^{72}$ Poster 143 in Materinstvo; Anna Krylova, "'Healers of Wounded Souls': The Crisis of Private Life in Soviet Literature," The Journal of Modern History 73, no.2 (2001): 324-9.

${ }^{73}$ For example, see "Otets narodov," and "Otets, drug, uchitel', vozhd'," Rabotnitsa 12 (1949): 1-2. This depiction of Stalin was not new. In the interwar era, official discourse promoted the Soviet Union as a "Great Family," with Stalin as the universal father. Katerina Clark, The Soviet Novel: History as Ritual (Bloomington: Indiana University Press, 2000), chap. 5; Susan Reid, "All Stalin's Women: Gender and Power in Soviet Art of the 1930s," Slavic Review 57,no.1 (1998): 133-73.

${ }^{74}$ For the medicalization of motherhood see Tricia Starks, The Body Soviet: Propaganda, Hygiene, and the Revolutionary State (Madison: University of Wisconsin Press, 2008), chap. 5.

${ }^{75}$ Sarah Ashwin, "Introduction," and Issoupova, in Gender, State, and Society, 11 and 31 , respectively.

${ }^{76}$ Ashwin, "Introduction," 12. Rebecca Neary, "Mothering Socialist Society," The Russian Review 58 (1999): 396-412.

${ }^{77}$ Sergei Kukhterin, "Fathers and Patriarchs in Communist and Post-Communist Russia," in Gender, State, and Society, 83.

${ }^{78}$ Mie Nakachi, "Population, Politics and Reproduction," in Late Stalinist Russia: Society between Reconstruction and Reinvention, ed. Juliane Furst (London; New York: Routledge, 2006), 26.

${ }^{79}$ Granat, Posledstviia, 26; Malinovskii, “Oshibka,” 31.

${ }^{80}$ TsGA NTMD UR, f. 1, o. 5, d. 810, 11. 4, 5, 15; FA 3 (1962): 54.

${ }^{81} \mathrm{Ibid}$, o. 4, d. 669, 11. 1, 137; Sadvokasova, Sotsial'no-gigienicheskie, 128.

${ }^{82}$ Nikonchik, "Problema," 4.

${ }^{83} F A 6$ (1970): 45.

${ }^{84}$ Nikonchik, "Dal'neiushie," 95; Dul'tsin, O vrede aborta, 4.

${ }^{85}$ Zdorov'e 12 (1962): 18; Kosoi, Abort ne prokhodit bessledno, 16.

${ }^{86}$ Sadvokasova, Sotsial'no-gigienicheskie, 136.

${ }^{87}$ Metodika sanitarno-prosvetitel'noi raboty po preduprezhdeniiu abortov (Moscow, 1965), 6.

${ }^{88}$ Dobrovol'skaia, Vred aborta, 3.

${ }^{89}$ Dul'tsin, O vrede aborta, 4, 54.

${ }^{90}$ For earlier literature, see N. Granat, Abort: Konspekt lektsii (Tula: Oblastnoe knizhnoe izdatel'stvo, 1951), 32; M. Serdiukov, Chem vreden i opasen abort (Moscow: 
Medgiz, 1954); V. Pokrovskii, Abort i ego vred (Voronezh: Voronezhskoe oblastnoe knigoizdatel'stvo, 1951). To be fair, some of the later texts blamed male and female influences. For example, see Kosoi, Abort ne prokhodit bessledno, 16.

${ }^{91}$ Granat, Posledstviia, 32. For similar ideas about men's responsibility to advise women against abortion, see G. Robachevskii, Gigiena braka (Moscow: Meditsina, 1969), 21.

${ }^{92} \mathrm{RGB}$, Inv \# 9325.

${ }^{93}$ E. Granat and A. Shibaeva, Materialy dlia sanitarno-prosvetitel'noi raboty sredi muzhchini po okhrane zdorov'ia zhenshchin (Moscow: Institut sanitarnogo prosveshcheniia, 1964).

${ }^{94}$ GARF, f. 8009 , o. 50, d. 3022, 1. 146.

${ }^{95}$ Field, Private Life, 88-92.

${ }^{96}$ Cohn, Disciplining the Party, 370.

${ }^{97}$ John Haynes, "Reconstruction or Reproduction? Mothers and the Great Soviet Family in Cinema after Stalin," in Women in the Khrushchev Era, 117-18.

${ }^{98}$ Julie Gilmour and Barbara Evans Clements, “'If You Want to Be Like Me, Train!': The Contradictions of Soviet Masculinity," in Russian Masculinities in History and Culture, ed. Barbara Evans Clements, Rebecca Friedman, Dan Healey (Basingstoke, UK: Palgrave, 2002), 221. 114-16.

${ }^{99}$ Tatiana Mamonova, ed., Women and Russia (Boston: Beacon Press, 1984),

${ }^{100}$ Nakachi, Replacing, 389-92; Carlbäck, "Lone Mothers," 93-5; and Sheila Fitzpatrick, Tear off the Masks: Identity and Imposture in Twentieth-Century Russia (Princeton, NJ: Princeton University Press, 2005), chap. 12.

${ }^{101}$ Elena Zdravomyslova and Anna Temkina, "Krizis maskulinnosti v pozdnesovetskom diskurse," in O muzhe $(N)$ stvennosti, ed. S. Ushakin (Moscow: Novoe literaturnoe obozrenie, 2002), 432-51. 